\title{
An Empirical Study on the Contribution of Foreign Trade to the Economic Growth of Jiangxi Province, China
}

\author{
Yuhong Li ${ }^{1,2}$, Zhongwen Chen ${ }^{2}$, Xiaoyin Wang ${ }^{3}$ \\ ${ }^{1}$ College of Economics and Management, Huazhong Agricultural University, Wuhan, China; ${ }^{2}$ Business School, Jinggangshan Uni- \\ versity, Ji'an, China; ${ }^{3}$ College of Science, Huazhong Agricultural University, Wuhan, China. \\ Email:wxywxq@126.com
}

Received March 19 ${ }^{\text {th }}, 2010$; revised April 20 ${ }^{\text {th }}, 2010$; accepted May $22^{\text {nd }}, 2010$.

\begin{abstract}
In open economy, development of foreign trade greatly impacts on GDP growth. Adapting simple regression for researching the relationship between foreign trade including total export and total import and GDP growth of Jiangxi province, with the collected 30-year statistical data from 1978 to 2007. The result indicates that foreign trade has contributed a lot to the GDP growth of foreign trade and still has great potential to be tapped. There is a positive correlation between the foreign trade and GDP. And import has influenced Jiangxi province's economic growth more and more. Finally, the paper points out that in order to maintain the economic growth, Jiangxi must unswervingly implement the opening-up policy and be aware of trade protectionism.
\end{abstract}

Keywords: Foreign Trade, Contribution, Simpler Regression

\section{Introduction}

Since the reform and opening up, China's foreign trade, which is playing a significant role in the world, has become more and more important [1]. But the proportion of China's total import volume in the GDP can not match the average level of the developed countries. Obviously, the foreign trade is closely related to economic growth in China. The importance of foreign trade for a country is increasingly prominent, though there are many researches related to contribution that foreign trade to GDP growth, researches particularly focus on one province or region is not common. Since the reform and opening up, foreign trade in Jiangxi province has experienced rapid development. From 1978 to 2007, exports and imports in Jiangxi province increased from 705.7 million dollars to 9.479 billion dollars [2].The increase of foreign trade is faster than the increase of GDP, and the proportion of foreign trade in GDP is increasing too. Therefore, this paper attempts to study on the contribution that foreign trade to GDP growth in Jiangxi province since the reform and opening up.

Many domestic scholars analyze foreign trade's contribution to GDP growth by studying the stimulating effect of net export. In four-sector economy,

$$
\begin{aligned}
\Delta \mathrm{GNP}= & \Delta \mathrm{C}+\Delta \mathrm{I}+\Delta \mathrm{G} \\
& +(\Delta \mathrm{X}-\Delta \mathrm{M})
\end{aligned}
$$

That's to say the GNP increment ( $\Delta$ GNP) equals the sum of consumption increment $(\Delta \mathrm{C})$ and investment increment $(\Delta \mathrm{I})$ and the government expenditure increment $(\Delta \mathrm{G})$ and the gross export increment $(\Delta \mathrm{X}-\Delta \mathrm{M})$. Therefore, the percentage of increase of GDP growth caused by foreign trade equals the product of GDP growth and the contribution degree of foreign trade to GDP growth. And the contribution degree of foreign trade to GDP growth equals the quotient of the net export increment divided by the GDP growth increment.

There is certain shortcoming in this method, which partially takes Keynes's view and simply regards import as an out leakage of GDP to attain the result that import has negative effect on GDP growth [3]. However, trade theory and practice proves that both import and export promote the national economy welfare and economic growth. For example, the import of cheap commodities can decrease production cost and increase consumers' welfare, and the import of capital goods and technology can promote the technological progress and improve labor productivity [4]. Therefore, we cannot simply consider only foreign trade export or net exports to the national economy and the influence of foreign trade should 
be from the aspects of national economic role in promoting the comprehensive analysis and evaluation. Therefore, the following will get down on each total foreign trade volume index, namely, the gross foreign trade (import and export), the gross import, the gross export and the net foreign trade (the balance of export and import)on analysis of several aspects of GDP. As a result, both import and export should be considered in research to evaluate their influence on national economy separately. This paper analyzes contribution of foreign trade to GDP growth from the perspective of foreign trade volume, import volume, export volume and the net export volume respectively.

The general idea of this paper is to use multivariate linear regression analysis method in econometrics, taking indices related to foreign trade as repressors and GDP as explained variable in this model. Then use SPSS 11.5 and Excel 2007 for statistical analysis in order to test foreign trade's contribution to GDP growth of Jiangxi province.

\section{The Construction of Model}

\subsection{Hypothesis}

Different indices related to foreign trade contribute to GDP growth in different degree.

\subsection{The Construction of Simple Regression Function}

$$
\mathrm{Y}=\mathrm{A}_{0}+\mathrm{A}_{1} \mathrm{X}+\varepsilon
$$

where $Y$ refers to the explained variable related to GDP growth. $\mathrm{X}$ is the variable related to foreign trade. $\mathrm{A}_{0}$ is the constant; $A_{1}$ is coefficient which stands for the degree of variable's increase caused by each unit's increase of explaining variables. As different indices are discussed in this paper separately, simple regression analysis is enough in the research.

Taking statistic data from 1978 to 2007 of Jiangxi province as sample, this paper analyzes foreign trade's contribution to GDP growth in Jiangxi province from four aspects including foreign trade volume, import volume, export volume and net export.

\section{Construction and Test of Econometric Model}

\subsection{Foreign Trade Volume's Contribution}

In order to reveal the total foreign trade's contribution to GDP, this paper analyzes the ratio of dependence on foreign trade and relation coefficient between foreign trade and GDP.

\subsubsection{The Ratio of Dependence on Foreign Trade}

The ratio of dependence on foreign trade is the ratio of total foreign trade in GDP, which reveals the dependency of a country's economy and the open level of the coun- try's market. Therefore,

Ratio of dependence on foreign trade $=$ total foreign trade/GDP

The result figured out according to the statistic data of foreign trade from 1978 to 2007 in Jiangxi province shows that the ratio of dependence on foreign trade in Jiangxi province, which has an overall increasing trend (see Figure 1), increased from $1.22 \%$ in 1978 to $12.67 \%$ in 2007. That's to say, the economic growth of Jiangxi province relies on the growth of foreign trade volume to a certain degree.

\subsubsection{Correlated Coefficient and Regression}

Based on above analysis and data, it can be found that there is linear correlation between foreign trade volume and GDP.

The following part analyzes foreign trade volume's contribution to GDP from the aspect of general correlation coefficient. The equation is

$$
\begin{gathered}
\rho_{\mathrm{xy}}=\frac{(\mathrm{x}, \mathrm{y})}{\sigma_{\mathrm{x}} \sigma_{\mathrm{y}}}, \sigma_{\mathrm{x}}=\frac{\sum\left(\mathrm{X}_{\mathrm{i}}-\mathrm{U}_{\mathrm{x}}\right)^{2}}{\mathrm{n}} ; \\
\sigma_{\mathrm{y}}=\frac{\sum\left(\mathrm{Y}_{\mathrm{i}}-\mathrm{U}_{\mathrm{y}}\right)^{2}}{\mathrm{n}} ; \operatorname{Cov}(\mathrm{x}, \mathrm{y})=\frac{\sum\left(\mathrm{X}_{\mathrm{i}}-\mathrm{U}_{\mathrm{x}}\right)\left(\mathrm{Y}_{\mathrm{i}}-\mathrm{U}_{\mathrm{y}}\right)}{\mathrm{n}}
\end{gathered}
$$

Based on the statistical data, the author analyzes the foreign trade volume of Jiangxi province from 1978 to 2007, and attains the general correlation coefficient $\rho=$ 0.971906 , so there is strict correlation between foreign trade volume and GDP.

However, how much has foreign trade volume stimulated GDP? Using general least square technique estimation to do further regression analysis, before which $\mathrm{T}$ test and $\mathrm{F}$ test are carried on.

Suppose Y stands for the total GDP, and XM stands for the total foreign trade volume. The result of the regression analysis is shown as the following:

The regression formula is,

$$
\begin{aligned}
& \mathrm{Y}=658575.03+8.276 X \mathrm{M} \\
& \mathrm{R}^{2}=0.927 \mathrm{~F}=358.82>\mathrm{F}_{0.05}=4.2
\end{aligned}
$$

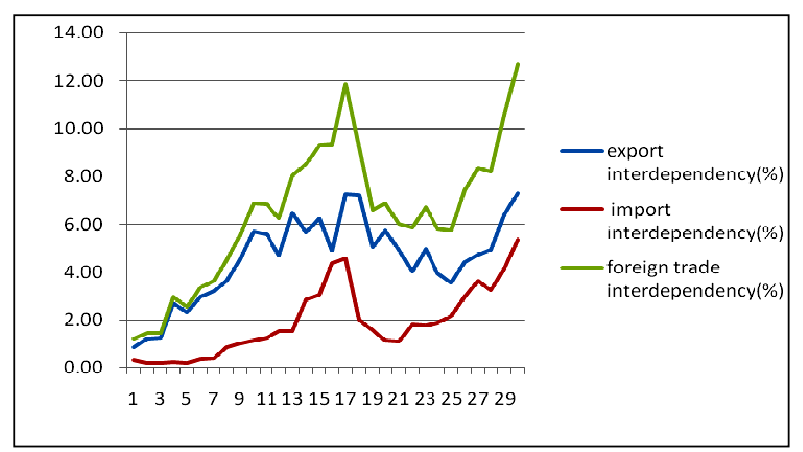

Figure 1. The trend of dependency of Jiangxi's GDP on foreign trade 
The regression results show that: (1) there is strong positive correlation between Jiangxi province's foreign trade volume and GDP, and the fitting degree shown as Figure 2, in which the purple line represents the regression line and $\mathrm{X}$ represents total foreign trade, is very good, which means that the expansion of foreign trade can promote economic growth; (2) the regression coefficient of total GDP and foreign trade is 8.276, which means that every US $\$ 1$ increase in foreign trade can increase US \$ 8.276 in GDP, and the marginal outputs of foreign trade is quite high. It further verifies the importance of developing foreign trade.

\subsection{Correlation between Export Volume and GDP}

\subsubsection{Ratio of Dependence on Export}

The ratio of dependence on export refers to the degree that a country's national economy relies on export. That is the proportion of export in GDP, which can be attained in the formula:

\section{Ratio of dependence on export $=$ export/total GDP}

Based on the statistical data, we have figured out the ratio of dependence on export increasing from $0.88 \%$ in 1978 to $7.30 \%$ in 2007 in Jiangxi province. It reached the peak in 2007 particularly. That' s to say, the degree that economic growth of Jiangxi province relies on the growth of foreign trade volume is overall increasing, especially during 1978 to 1994.

\subsubsection{Correlated Coefficient and Regression Analysis}

Suppose Y stands for the total GDP, and X stands for export. Using general least square technique estimation to do further regression analysis on the bases of the certain data, and the result is shown as the following:

The regression formula is,

$$
\begin{aligned}
& \mathrm{Y}=495610.794+14.420 \mathrm{X} \\
& \mathrm{R}^{2}=0.930 \mathrm{~F}=374.495>\mathrm{F}_{0.05}=4.2
\end{aligned}
$$

The regression results show that: (1) there is strong positive correlation between Jiangxi province's export and GDP, and the fitting degree shown as Figure 3, in which the purple line represents the regression line and $X$ represents export, is very good, which means that the expansion of export can promote economic growth; (2) the regression coefficient of total GDP and export is 14.42 , which means that every US \$ 1 increase in export can increase US \$ 14.42 in GDP, and the marginal outputs of export is quite high. It proves the rationality of export-led economy.

\subsection{Correlation between Import Volume and GDP}

\subsubsection{Ratio of Dependence on Import}

Similar to the ratio of dependence on exports, the ratio of dependence on import refers to the degree that a country's national economy relies on import. That is the proportion of import in GDP, which can be attained in the formula:

Ratio of dependence on import $=$ import/total GDP

Based on the statistical data, we have figured out the ratio of dependence on export in Jiangxi province increasing from $0.34 \%$ in 1978 to $5.37 \%$ in 2007 . It reaches the peak in 2007 particularly. That's to say, the degree that economic growth of Jiangxi province relies on the growth of foreign trade volume is still overall increasing, but import falls in some years due to certain reasons.

\subsubsection{Correlated Coefficient and Regression Analysis}

Suppose Y stands for the total GDP, and M stands for import. Using general least square technique estimation to do further regression analysis on the bases of the certain data, and the result is shown as the following:

The regression formula is,

$$
\begin{aligned}
& \mathrm{Y}=899939.8024+18.98 \mathrm{M} \\
& \mathrm{R}^{2}=0.904 \mathrm{~F}=263.69>\mathrm{F}_{0.05}=4.2
\end{aligned}
$$

The regression results show that: (1) there is strong positive correlation between Jiangxi province's import and GDP, and the fitting degree shown as Figure 4, in which the purple line represents the regression line and $\mathrm{X}$ represents import, is very good; (2) The regression coefficient of total GDP and import is 18.89, which means

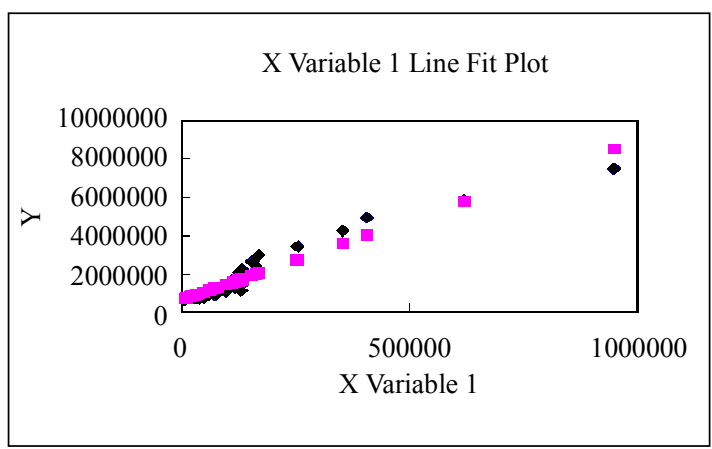

Figure 2. The fitting effect of GDP and foreign trade volume

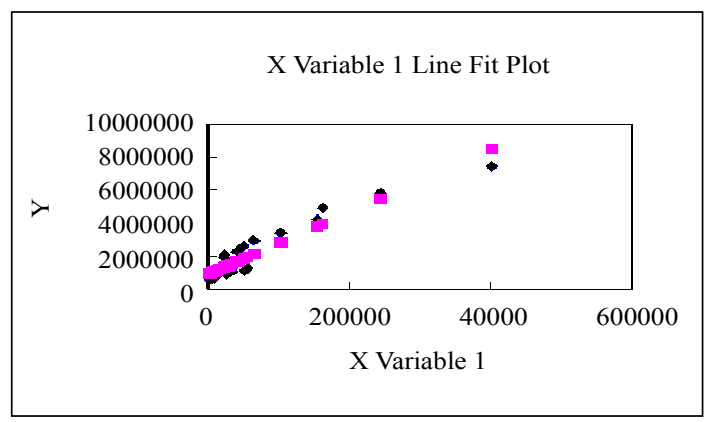

Figure 3. The fitting effect of GDP and export 
that every US \$ 1 increase in import can increase US \$ 18.89 in GDP, and the marginal outputs of export is quite high. It shows that Jiangxi province is performing well in import and in order to achieve the objective of opening up, the import should be further encouraged.

\subsection{Correlation between Net Export Volume and GDP}

In order to study the final factor of foreign trade contributed to economy, the paper analyzes the net export too. According to $\mathrm{Y}=\mathrm{F}$ (K, L, X - M), the net export obviously promote economy. The net export is represented by $(\mathrm{X}-\mathrm{M})$, Using general least square technique estimation to do further regression analysis, and the result is shown as the following:

The regression formula is,

$$
\begin{gathered}
\mathrm{Y}=53732.69+41.386(\mathrm{X}-\mathrm{M}) \\
\mathrm{R}^{2}=0.7 \mathrm{~F}=65.039>\mathrm{F}_{0.05}=4.2
\end{gathered}
$$

The regression results show that: (1) there is strong positive correlation between Jiangxi province's net export volume and GDP, and the fitting degree shown as Figure 5, in which the purple line represents the regression line and $\mathrm{X}$ represents net export, is very good, which means that the expansion of net export can promote economic growth; (2) the regression coefficient of total GDP and net export is 41.386 , which means that every US \$ 1 increase in foreign trade can increase US \$ 41.386 in GDP, and the marginal outputs of foreign trade is remarkable high. That's to say, Jiangxi could pursue trade surplus

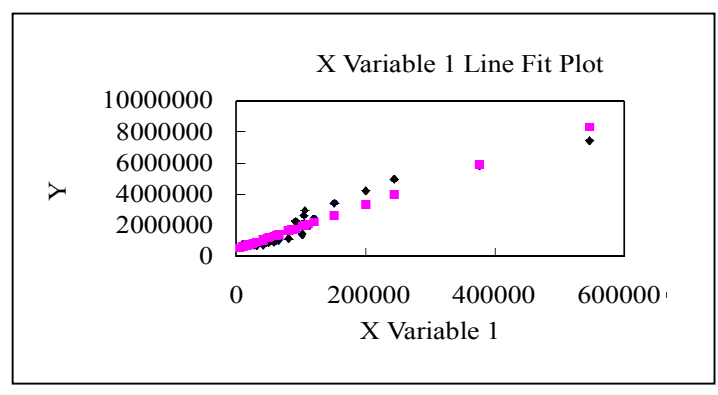

Figure 4. The Fitting Effect of GDP and Import

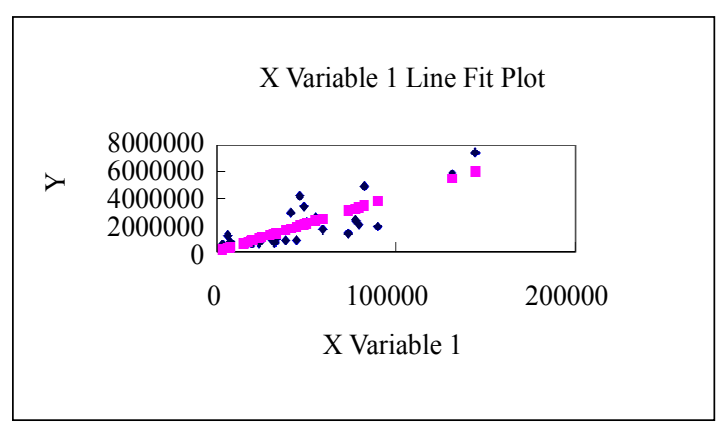

Figure 5. The fitting effect of GDP and net export aimlessly. It can help to accumulate the capital and foreign exchange deposit so that to enhance higher speed of economic growth.

\section{Conclusion and Discussion}

1) The empirical study suggests that the total foreign trade volume, the import volume, the export volume and the net export volume all have strict correlation ship with Chinese Jiangxi Province's GDP. One should be paid more attention to is that the correlation between import and GDP is bigger than that between export and GDP. That is to say, import plays better than export in stimulating GDP growth. This result tells us that Jiangxi could not ignore the impact of import on stimulating economy while enhancing export, and the contribution of import to GDP growth at any time, or restrict the import to pursue foreign exchange deposit, and could not follow America to buy "CHINA" either.

2) With deepening the reform and opening-up, the rate of foreign trade dependence is becoming bigger increasingly; the correlation between GDP and export as well as import is enhanced year by year. Although the improvement of foreign trade in Jiangxi to GDP growth is less than that in some of eastern provinces, Jiangxi, as an inner province, without geography location advantage, its export-led economy still has a wonderful future as long as it can make the most of each kind of resources.

3) Keynes, a famous economist, ever said: "export is for better import". That is to say, export is to provide with better situation to support importing what we don't have or more efficient products. As an inner province, though Jiangxi can make the most of its resources and improve its employment rate, it could not restrict import while expanding export. Otherwise, it will slow down the speed of improving the living level of the people in Jiangxi. Simultaneously, it will be harm for the effective use of global resources and for the integration as well.

While, future research should be proceeded. As being known that linear regression is based on the hypothesis that the linear relationship between foreign trade and economic growth is true, but in fact, it may be not perfect to research the above issue. So we should adapt more advanced methods for researching the casualties between foreign trade and economic growth. Whether there exists long time or short term stable causalities could be further researched in the future.

\section{Acknowledegments}

This paper is assisted by the projects: Jiangxi provincial Co-operated Social Science Projects, A Study on the Development of Service Industry and Trade in Service in Jiangxi Province (Project ID: 09YJ249) and A Research on the Evolution of the Spatial Economy in Jiangxi and Agglomeration of Industry (Project ID: 09YJ245); A 
Study on the Development of Logistics in Ji'an City Based on the Theory of Industry Cluster (Project ID: JR0816).

\section{REFERENCES}

[1] J. Li, "A Study on the Foreign Trade during Chinese Economy Growth," Ph. D. Dissertation, College of Economics, Jilin University, June 2006.

[2] China Statistic Bureau, "China Statistics Year Book,"
China Statistics Press, Beijing, 2008.

[3] X. P. Liu, "An Empirical Study on Chinese Import and Export and Economic Growth-Research the Improvement of Foreign Trade to Economic Growth from the Growth Rate," Journal of Modern Economic Science, Vol. 3, 2001, pp. 55-60.

[4] X. M. Wang, "The All-Side Analysis of New International Trade," People's University of China Press, Beijing, January 2000. 